\title{
AN ANALYSIS ON THE MEANING IN HOMBO BATU CULTURE IN BAWOMATALUO VILLAGE, TELUK DALAM
}

\author{
Adrianus Tafonao (Corresponding Author) \\ English and Literature Department, Kanjuruhan University of Malang \\ Jl. S. Supriadi 48 Malang 65148, East Java, Indonesia \\ Phone (62) 82232112991 E-mail: adritafno@ gmail.com \\ Arining Wibowo \\ English and Literature Department, Kanjuruhan University of Malang \\ Jl. S. Supriadi 48 Malang 65148, East Java, Indonesia \\ Phone (62) 85646389803 E-mail: cacamarisa90@yahoo.com \\ Maria G. Sri Ningsih \\ English and Literature Department, Kanjuruhan University of Malang \\ J1. S. Supriadi 48 Malang 65148, East Java, Indonesia \\ Phone (62) 85933033177 E-mail: m.g.sriningsih@gmail.com
}

\begin{abstract}
Hombo Batu is formed because in ancient times there was a war between villages. So that every village had to find a way to defend their village, one of which they did was to close each of their villages, ranging from bamboo which were made sharp as a spear as a form of defense. However, chiefs were also looking for the soldiers, who asked the youngsters to jump over the fence ranging from 4 meters, but because it was too high chieftain change the height to 2 meters so that the young people were able to jump over the fence then the commander will make them as soldiers. At the time, the form of the fence was also different, not like bamboo, but from stones that have been arranged as high as 2 meters. This study aims to analyze the original meaning of Hombo Batu culture itself, so that people know the true meaning in Hombo Batu culture. Researcher has some research problems, there are: the meaning of Hombo Batu culture, the functions of Hombo Batu culture, the factors which affect of the shifting in Hombo Batu culture, the effort of Bawomatoluo population to maintain the Hombo Batu culture. Data collection is done by field notes and interviews of heads of tribes, stone jumpers, and the people in the Bawomataluo village, to obtain the desired data. The data are taken from data in Hombo Batu culture, to analyze data the researcher use using triangulation method. In this study the researcher will use data triangulation and methodological triangulation. Methodological triangulation which refers to the use of more than one method for gathering data. Output obtained in the form of grouping the opinion of the society that shows whether it is the original meaning in Hombo Batu culture or not. The researchers concluded that the true meaning of Hombo Batu is as establishment of warriors to defend their villages, is not a requirement to get married. However, because this time the war between villages is no longer there, then Hombo Batu become one of the tourist places can be visited by anyone and from anywhere.
\end{abstract}

Key Terms: culture, meaning, Hombo Batu culture 


\section{Introduction}

The culture diversity of Indonesia, especially North Sumatra very attractive to studied and researched. The culture can be visualized through language. With the language, the culture, the culture can be known and grown in the community. According to Algeo (2005: 2) language is a system of conventional vocal signs by means of which human beings communicate.

Language serves as a means of communication in a member of society that wear language and documentation activity or the activity of human life. According to Halliday, 1985 (in Malinowski 1923) the language has two function that is, function of pragmatic and function of magical. The function of language in pragmatic covering the use of language active and narrative, while the function of language in a magical manner as do users of languages in activities related to ritual of customary or religious ceremony in a culture. Culture refers to various aspects of life that includes ways, attitudes and beliefs toward something. In other words, culture is a learned behavior is configuration. Then the behavior supported and passed by members of the society. According to Fernandes, (1990), culture is highest norm in daily life of the community which controls social relationship cosmic (natural) form of the cult (worship) and rites (ceremony). Indonesia has unique tradition art forms and diverse which is often local culture referred to as living in the midst of society. Despite the supporting of society getting changes, the traditional art developed by following the dynamics. Art as one of the elements of culture is a reflection of the mindset, behavior, and character of the society owner. In principle, an art form created to satisfy human needs in order to feel at ease in the face of natural challenge. One such tribe is the people of Teluk Dalam people, Nias Island. The island is inhabited by a majority of the Nias tribe or Nias people called them is Ono Niha, who has a megalithic culture, music, dance, singing (sinunö), and Hombo Batu. Hombo Batu is one of popular culture in the world; it has a special attraction for the tourist. Culture is the system totalities, ideas, actions, and products of human endeavor in the context of a society that belongs to human beings used as a way of learning (Koentjaraningrat, 1997:4). Culture is as communication and identity of society that must be preserved. Moreover, culture has an important role in facilitating for the relationship between one and others. This fact can be found in the Nias ethnic which is one 
of the residing in the province of North

Sumatera. Nias people really appreciate for any cultural elements in their lives and make the cultural elements to be something that is very sacred and must be followed and obeyed by all of people in Nias. In Nias culture there a lot of diversity of cultural. One of them is Hombo Batu. Hombo Batu is one of the very unique culture and interest for the attention of the world. The uniqueness of Hombo Batu culture is where a man in the Bawomatoluo village will jump over 2 meters high rock. The emergency of Hombo Batu in the beginning is not as a sport or entertainment only as we are witnessing today. Hombo Batu has a history that is loaded by the war, patriotism and heroic nature. According Mr. Emanuel Fau was echoed by Mr. Amuri Zebua (custom head). Fau is the fourth son of the leader of Hiliametaniha area, at the first hombo batu appeared because of frequent inter-regional war. Because of the war, hombo batu was getting a shift in form, function and meaning. The researcher explained before that Hombo Batu appeared because of frequent interregional. In this time, we living in modern era, so all of culture can get a change.

\section{Literature Review}

Culture is similar to the system of symbols that is a reference and guidelines for the life of the community in terms of providing the meanings that are transmitted through the symbolic codes. Culture refers to the cumulative deposit of knowledge, experience, beliefs, values, attitude, meanings, hierarchies, religion, notions of times, roles, spatial relations, concepts of the universe, and material objects and possessions acquired by a group of people in the course of generations through individual and group striving. Rohendi (2000:3). Attempts to understand the meaning of, it is one of the problems of philosophy. Concept of meaning has attracted the attention of the communication discipline, psychology, sociology, anthropology, and linguistics, that's why some experts often refer to "meaning" when they define communication. Stewart L. Tubbs and Sylvia Moss (1994:6) said that communication is process of meaning between two or more people (Sobur, 2001:255). Ogden and Richards (1972, 186-187), The meaning of Meaning, said that has collected approximately 22 restrictions on meaning. However, meaning including in the linguistics field (Sobur, 2001: 255). The culture system, if many people communicate so we can understand more about meaning. Since Plato, 
John Locke, Witt Geinstein, until Brodbeck (1963), was meaning defined by the description and more often confusing than explaining. In this case, meaning has 3 types who divided by Brodbeck, there are:

a) Inferential meaning is the meaning of the word (symbol) objects, thoughts, ideas, concepts referred to by the word. In the description of Ogden and Richards (1946), the process of giving meaning (reference process) occurs when we connect the symbol with the symbol shown itself (called a referral or referent).

b) Meaning that showed significance is a term that is associated with other concepts, for example, a object can flaming because phlogiston is there, now after the discovery of oxygen, phlogiston not matter anymore.

c) Intentional Meaning is a meaning that is meant by a user symbol. This meaning can be validated empirically or look for referral. This meaning is not only in one's mind alone (Sobur, 2004: 263).

Basically, meaning is in our mind, no in a symbol. If there are people who say that words have meaning, which meant is that the words were encouraging people to give meaning (which has been agreed together) to the word itself. Meaning arises because of different life experiences. Person, for each, has their own definition of the meaning. This could be called individual meaning, but if all the meanings is individual meaning, certainly not communication with other. Meaning can be classified in two kinds, denotative and connotative. Denotative is the real meaning as we find in the dictionary, denotative is public, there are a number of words that are denotative but also there are significant connotative, more personal, the meaning beyond its objective reference. In other words, connotative meaning is more subjective than denotative meaning.

\section{Methodology.}

3.1 Research Design. The researcher uses the qualitative method. Qualitative research is concerned with understanding the social phenomenon from the participant's perspective. Understanding is acquired by analyzing the many contexts of the participants and by narrating participant's meanings for these situations and events. Participant's meanings include their feeling, beliefs, ideas, thoughts, and actions (Malinowski: 1922:373). 
3.2 Data and Source of Data. Collecting

the data, the researcher uses Hombo Batu tradition as the subject of this study.

Researcher watched that Hombo Batu tradition closely. By having watch closely that event which such qualification, hopefully, the researcher gets as valid and accurate data as possible.

\subsection{Instrumentation. The researcher} necessary to use some of instrumentations, these instruments are: observation, interview, and documentation to collect the accurate data.

\subsection{Data Collection. Procedure of}

collecting data consists of detailed descriptions of situations, events, people, interactions, and observed behaviors; direct quotations from people about their experiences, attitudes, beliefs, and thoughts, and quotations from documents, correspondence, and records. The detailed description, and case documentation obtained by qualitative methods are raw data from the empirical world. The data are collected as open-ended narrative. Lofaland $(1971 ; 6)$ has suggested that there are four elements in the collection of qualitative data: first, the qualitative methodologist must get close enough to the people and situation being studied to be able to understand the depth and details of what goes on. Second, the qualitative methodologist must aim at capturing what actually takes place and what people actually say. Third, qualitative data consist of a great deal of pure description of people, activities, and interactions. Next, qualitative data consist of direct quotations from people, both what they speak and what they write down. In the collecting the data, the researcher gets his data from subject and object by using different techniques. The data for this thesis were collected from some books, internet that concerning with the thesis and from the informant who know well about Nias culture especially in Hombo Batu culture.

\subsection{Data Analysis. Miles and Huberman} (1994) suggest that qualitative data analysis consists of three procedures:

1. Data reduction. Data reduction refers to the process of selecting, focusing, simplifying, abstracting and transforming the data that appear in written field notes or transcriptions. This refers to the process whereby the mass of qualitative data the researchers may obtain - observation, interview documentation,etc. - is reduced and organised, for example 
coding, writing summaries, discarding irrelevant data and so on.

2. Data display. In the data display the researchers will be use code of the data. To draw conclusions from the mass of data, Miles and Huberman suggest that a good display of data, in the form of tables, charts, networks and other graphical formats is essential. This is a continual process, rather than just one to be carried out at the end of the data collection.

3. Conclusion drawing/verification. The analysis should allow you to begin to develop conclusions regarding your study. These initial conclusions can then be verified, that is their validity examined through reference to your existing field notes or further data collection. In verification of data the researchers will be use triangulation.

\subsection{Validity of Data. In qualitative}

research, validity concerns the degree to which a finding is judged to have been interpreted in a correct way. To avoid misinterpretation of the data in this study, the researcher uses triangulation especially triangulation data sources. According to Denzin and Lincoln source triangulation
Volume 2 Nomor 2 Desember 2015

involves gathering data from multiple sources in order to minimize and understand any differences held by in various roles. Triangulation is typically a strategy (test) for improving the validity and reliability of research or evaluation of findings. In this section, the researcher uses triangulation on his thesis. Triangulation is one of important techniques that used by the researcher to measure whether the data can be trusted or not. In this case, the researcher has to make a communication with other people in comparing notes to extend the researcher's mind. Here, there are a few steps used in this technique to make sure that the data is still valid. Firstly, the researcher watches the video of the ceremony in order the data he collected are appropriate with source. Secondly, the researcher consulted the data with some friends in obtaining more important information to add the researcher knowledge in finishing his analysis. Finally, the researcher discussed the data that he got with Mr. Sujito. This is a way for getting the different ideas which useful for an expanding analysis and also to know the validity of the data. 
Volume 2 Nomor 2 Desember 2015

Result and Discussion

Result

4.1.1 The Meanings of Hombo Batu. The meaning of Hombo Batu is as means of training to become a soldier in the battlefield. However, war is no longer there. Thus, whether the Hombo Batu eventually loses its meaning? Of the few records that were collected through direct interview to stone jumper both adult and young, it can be concluded that the meaning of Hombo Batu for stone jumper is a means to an end to achieve the future, in addition to pride as a patriot. If the meaning of Hombo Batu originally coined by Amada Samofo is to defend the area from invasion Laraga Maenamolo so descendants Mölö still exist today, then the meaning of Hombo Batu today for the younger Maenamölö generation is to achieve the ideals in achieving a more prosperous future. Hikayat Manaö as Zaluaya Commander in the Bawömataluo village said that the understanding and meanings like that is mistaken. Hombo Batu was originally a benchmark for the village youth in the area Maenamölö to be a warrior in the face of enemies who want to dominate the region. As the changing times, where there are no more wars and even more dominant economic power in social life, then Hombo Batu turned into a means of agility training the village youth, as sports facilities high jump, and as a challenge to join the race Hombo Batu on each events held both in the area of South Nias, as well as outside Nias, as the identity of the pride of the culture diversity of the archipelago. Mr. Emanuel Fau as the originator descent Hombo Hatu in Maenamölö, also questioned the origin of the conclusions which he said was less relevant. "How could all Nias youth must jump over the high stone?" An erroneous conclusion regrettable by Mr. Emanuel Fau is very reasonable because each person has different skills. Anyway, at first, si'ulu may not do Hombo Batu. It is precisely this group who chose the soldiers by challenges Hombo Batu, so that youth who are hungry for recognition of the si'ulu will strive to become warriors, in order to obtain fondrakö or prizes and awards. The same thing was said by Mr. Bajamaoso Fau as the customary head of the Bawömataluo village. He said that the meaning is not to be taken but it needs to be clarified. "It is not true that it is able to jump the stone as a condition for Nias youth to marry or as a sign of maturity," he says. Mr. Bajamaoso Fau explained that the emblem of 
the establishment, and is considered an adult is when someone in antiquity able fa'ulu that have materially can be independently so as to entertain banua (villagers) with a minimum of nine pigs slaughtered. In addition, the young man in question was also able to meet the demand honesty filed by the family of the girl who wants to marry, in Gana'a stone size (value-carat gold). He added that the current trend, it is the ability of the economy and education degree is more recognized and proud than Hada Si'ulu title. In public life today, Bowo or honesty it should not be forgotten, especially abandoned. Should be preserved but should be adapted to the changing times.

\subsubsection{The functions of Hombo Batu.}

Hombo Batu is a very popular tradition in Nias society, in South Nias. This tradition has been done for a long time and handed down for generations by people in the Bawomataluo village (Hill of the Sun). Hombo Batu culture has been done since the days of the ancestors, where in anciently times they were often at war among tribes so that they train themselves to be strong and capable of penetrating the fortress opponents who supposedly high enough to jump. Along the development era, this tradition also changes its function.
Because today they are no longer fighting so the tradition of the Hombo Batu was not for war but for rituals and also as a symbol of the culture of Nias. Hombo Batu tradition is a rite of culture to determine whether a young man in the Bawomataluo village can be recognized as a young adult or not. The young men will be recognized as a brave man if they can jump over a pile of rocks that are made in such a way those more than two meters high. There is a special ritual before the youth jump. While wearing traditional clothes, they ran with a small stepping stone buttresses in advance to be able to pass through the high stone buildings. Until now this tradition still exist in modern culture increasingly choke.

\subsubsection{The forms of Hombo Batu. As}

described in its history that at the first Hombo Batu was not such as we are witnessing today. Starting from 4-meter-high bamboo made sharp edges so as to frighten the enemy to pass through villages in Maenamölö. Hombo Batu form is known today as the pyramids. Thus, in addition to stone jumper can jump high, should also be able to jump away. That is, soldiers who were elected are the ones who have the formidable ability. In the times, the Hombo Batu was not immune from shifts of form, because the original of Hombo Batu 
Volume 2 Nomor 2 Desember 2015

only in South Nias and is very difficult to obtain in other areas. In fact, Hombo Batu performances often received a request from Hombo Batu fans to witness the attraction though outside Nias. Thus, sparked new ideas for making imitation stone that can be transported or can be moved from one place to another. Thus, creating a Hombo Batu imitation stone made of boards or plywood, molded such that the physical of form and same with the original stones found in traditional villages in South Nias.

\section{The Factors that Affecting of the Shifting in} Form, and the Meaning in Hombo Batu culture

\subsubsection{The Shifts of Meaning in Hombo Batu}

Culture. Based on the history, the meaning of Hombo Batu is as means of training to become a soldier in the battlefield. However, war is no longer there. Thus, whether the Hombo Batu eventually loses its meaning? Of the few records that were collected through direct interview to stone jumper both adult and young, it can be concluded that the meaning of Hombo Batu for stone jumper is a means to an end to achieve the future, in addition to pride as a patriot. If the meaning of Hombo Batu originally coined by Amada Samofo is to defend the area from invasion Laraga Maenamolo so descendants Mölö still exist today, then the meaning of Hombo Batu today for the younger Maenamölö generation is to achieve the ideals in achieving a more prosperous future. As told by Hikayat Manaö as one of the mainstays stone jumper in Bawömataluo village in the 1980 s, that a stone jumper, has hope will change the future into a better direction. Evidently, the action in doing the Hombo Batu invites admiration II Bukit Barisan Military Commander, Susilo Soedarman when he visited the village of Bawömataluo early 1980. All three of them, Hikayat Manaö, Hadirat Manaö and Fanahatödö Manaö trained as soldiers. Although for personal reasons, Hikayat Manaö changed his mind to be a soldier and choose to promote arts and culture in the village, Bawömataluo.

In addition to seize the future, meaning Hombo Batu for stone jumper is a pride to preserve the unique tradition that is second to none. This was disclosed by subscription contemporary Hombo Batu champion, Darius Bu'ulölö said that "We are quite proud that could traverse the stone. We practiced continuously; so that this culture can still we inherited. Darius Bu'ulölö who works not as 


\section{Jurnal Ilmiah Bahasa dan Sastra}

ISSN : 23557083

Volume 2 Nomor 2 Desember 2015

high jump athlete, but he is a temporary employee in the municipal police Teluk

Dalam. Although widely, function and meaning of Hombo Batu finally many "displaced", many miss the mark with what is told and believed the traditional elders in Nias but Hombo Batu remains an attraction for tourists. There are some erroneous conclusions about the function and the meanings of Hombo Batu in Nias were already widespread. First, for young people who go abroad Nias and asked the status of his marriage, when he said "already married", often followed by "question-conclusion" as some of the following sentences:

"Wah, can you do fahombo (jump stone)?"

"Oh, you are very great?"

Second, in the social media is often written that Hombo Batu is "a sign of maturity for a young Nias and ready to get married". Third, the more extreme is that Nias youth "should not be married if cannot do Hombo Batu. Hikayat Manaö as Zaluaya Commander in the Bawömataluo village said that the understanding and meanings like that is mistaken. Hombo Batu was originally a benchmark for the village youth in the area Maenamölö to be a warrior in the face of enemies who want to dominate the region. As the changing times, where there are no more wars and even more dominant economic power in social life, then Hombo Batu turned into a means of agility training the village youth, as sports facilities high jump, and as a challenge to join the race Hombo Batu on each events held both in the area of South Nias, as well as outside Nias, as the identity of the pride of the culture diversity of the archipelago.

Mr. Emanuel Fau as the originator descent Hombo Hatu in Maenamölö, also questioned the origin of the conclusions which he said was less relevant. "How could all Nias youth must jump over the high stone?" An erroneous conclusion regrettable by Mr. Emanuel Fau is very reasonable because each person has different skills. Anyway, at first, si'ulu may not do Hombo Batu. It is precisely this group who chose the soldiers by challenges Hombo $B a t u$, so that youth who are hungry for recognition of the si'ulu will strive to become warriors, in order to obtain fondrakö or prizes and awards. The same thing was said by Mr. Bajamaoso Fau as the customary head of the Bawömataluo village. He said that the meaning is not to be taken but it needs to be clarified. "It is not true that it is able to jump 
the stone as a condition for Nias youth to marry or as a sign of maturity," he says. Mr. Bajamaoso Fau explained that the emblem of the establishment, and is considered an adult is when someone in antiquity able fa'ulu that have materially can be independently so as to entertain banua (villagers) with a minimum of nine pigs slaughtered. In addition, the young man in question was also able to meet the demand honesty filed by the family of the girl who wants to marry, in gana'a stone size (value-carat gold). He added that the current trend, it is the ability of the economy and education degree is more recognized and proud than hada si'ulu title. In public life today, Bowo or honesty it should not be forgotten, especially abandoned. Should be preserved but should be adapted to the changing times. Heryanto's article above is a phenomenon that is also being experienced by Maenamölö culture, especially in the village of Bawömataluo. Through the uniqueness of the show Hombo Batu, several series of activities or cultural rituals in the kingdom in an interesting way Maenamölö packed into a tourism product. Such activities that support the show Hombo Batu, among others:

a. Perang Dance or Fataele
Perang Dance is a symbol of the young knight in the villages in South Nias, to protect the village from the enemy threat, which begins with Fana'a or in Indonesian called Ronda. By the time the patrol if there are cue that the village had been attacked by the enemy then all come together to attack the enemy troops. Once an enemy is attacked, then the severed heads of enemies to be presented to the King.

b. Mogaele Dance

Mogaele basically not a dance but rather on performing ritual welcoming guests highly respected. Customary head Hiliamaetaniha Village well as expert said South Nias, Mr. Amuri Zohahau Wau said that "Mogaele is a form of respect for the Supreme Guests are greeted by some of the girls or women who are beautiful, elegant and well respected by everyone because they are polite behavior spoken, has charisma and dignity. The way of these girls walk very slowly and gently. In Nias language, way of walking is called Mogaele or ifahese vofanő (stepping with foot dragged very slowly by hand movements like marching) so it seemed like everyone was dancing. 
c. Famadaya Harimao

At the time, Famadaya Harimao is one of the ancient sacred religious ceremonies before Christianity came to Nias. Famatő Harimao was a procession of the statue of a tiger. After the statue was paraded, then broken and thrown into a river or a waterfall in the belief that all sin, transgression, mistake they have done will drift along with the statue. Famato

Harimao, has nothing to do with the real tiger animal does not exist in Nias. Here need compactness team in each leg movements are accompanied by parading a statue harimao.

d. Maena Dance

Maena is a dance that is very easy and simple, but it contains the meaning of togetherness, joy, excitement, which is not less interesting with dances in the archipelago. Compared with baluse dance / perang dance, maena does not require any special skills. Simple movements have made almost everyone can do. Constraints or difficulties sole is located in the circuitrhyme rhyme maena (fanutunõ maena), in order to conform to the event where maena it done. Maena poetry (fanutunõ maena) is usually performed by one person or two people and is referred to as sanutunõ maena, while maena poetry (fanehe maena) voiced by many people who took part in the maena dance and referred to as sanehe maena / ono maena.

\subsubsection{The Shifts of Form in Hombo Batu}

Culture. At the first time Hombo Batu is not such as we are witnessing today. Starting from 4-meter-high bamboo made sharp edges so as to frighten the enemy to pass through villages in Maenamölö. Because bamboo is broken and thin surface, bamboo as a palisade increased to clay. But clay is not resistant to weather; so the society built a tiered stone to jump as high as up to 2.5 meters. Hombo Batu is known today as the pyramids. Thus, in addition to stone jumper can jump high, should also be able to jump away. That is, soldiers who elected are the ones who have the formidable ability. In the times, the Hombo Batu was not immune from shifts of form because the original of stones in South Nias is difficult to obtain in other areas. In fact, Hombo Batu performances often received a request from Hombo Batu fans to witness the attraction though outside Nias. Thus, sparked new ideas for making imitation stone that can be transported or can be moved from one place to another. Thus, creating a Hombo Batu imitation stone made of boards or plywood, 
molded such that the physical of form and same with the original stones found in traditional villages in South Nias.

\subsubsection{The Efforts of Bawomataluo Society to} Maintain the Hombo Batu Culture. Hombo

Batu is a culture that is very popular in the Nias Island, even in the world. Whereas Hombo Batu culture is inherited from the ancestors that must be guarded and preserved. Along the development era, the changeing always happens in every culture, even experienced several changes of meaning, function, and others. Then, whether we have to maintain that culture? What should we do? The culture should be preserved, maintained if we love our culture. We maintain a culture because the culture is a heritage which has historical and cultural value is very high. One of the stone jumper in the 1980s, Mr. Hikayat Manao said that culture is our life, culture is our lifestyle. When the researcher asked the efforts to maintain the culture of Nias, especially Hombo Batu to Mr. Hikayat Manao, he just said, "as long as I am alive, so cultural Hombo Batu will always live, if there are people who dare to change the culture Hombo Batu then that person must confront me ". A few years ago, the Indonesian government had offered to society of Bawomataluo to change the position of Hombo Batu by rebuilding / construct a more modern rock, but all the villagers in Bawomataluo will reject it. Mr. Hikayat Manao said that "the others culture you may offer to it but never offered to the Bawomataluo village because we will never accept the offer, because like any form, function, and meaning of Hombo Batu culture from the past until now so still as it is, there should be no change, etc. If one day I was on the call by God then I never worry about Hombo Batu culture because now the young people, especially in the Bawomataluo village will be taught how they should preserve the heritage, even some young people who already started training for jumping over the rock, we are proud to have Hombo Batu culture.

Based on research data that has been obtained, the researcher concluded that the true meaning of Hombo Batu is as establishment of warriors to defend their villages is not a requirement to get married. However, because this time, the war between villages is no longer there, then Hombo Batu become one of the tourist places can be visited by anyone and from anywhere. Hombo Batu is also one culture that helps people in the economy. Every tourist who ask stone jumper to Hombo Batu attractions, has to pay Rp. 
Volume 2 Nomor 2 Desember 2015

200.000 / jump. Hombo Batu became the one of the culture is very popular and admired by many people and even the world until now. So these cultures should remain in care, and retained because it has a special attraction and unique.

\section{Conclusion and Suggestion}

Conclusion.

In this part, the researcher concludes that Hombo Batu culture is an event which shows the significant phases of life for Bawomataluo Village. The ritual of Hombo Batu culture is an inheritance that should be protected and preserved, because this ritual revealed the deepest meaning of the people in the village. This culture is rich of the meaning. But many people did not know about the real meaning of Hombo Batu culture itself.

The process of Hombo Batu culture is divided into some steps that should be passed by Perang Dance or Fataele (a symbol of the young knight in the villages in South Nias, to protect the village from the enemy threat, which begins with Fana'a or in Indonesian called ronda), Mogaele Dance (Mogaele basically not a dance but rather on performing ritual welcoming guests highly respected),
Famadaya Harimao (one of the ancient sacred religious ceremonies before Christianity came to Nias), Maena Dance (a dance that is very easy and simple, but it contains the meaning of togetherness, joy, excitement, which is not less interesting with dances in the archipelago).

Besides, this ceremony has its own characteristics and values which reflecting all about social life of Bawomataluo society.

Basically, the real meaning in Hombo Batu culture is formed because in anciently times there was a war between villages so that every village had to find a way to defend their village, one of was to close each of their villages, ranging from bamboo which were made sharp as a spear as a form of defense. However, chiefs were also looking for the soldiers, who asked the youngsters to jump over the fence ranging from 4 meters, but because it was too high chieftain change the height to 2 meters so that the young people were able to jump over the fence then the commander will make them as soldiers.

At the time, the form of the fence when it was also different was not like bamboo, but from the stones that have been arranged as high as 2 meters. However, many people who say that the meaning of the Hombo Batu that 
young people are able to jump over the stone

can be said already mature and get married.

According to the Mr. Hikayat Manao as a stone jumper in era 1980 that it's wrong, it is just assuming a lot of people, but the original meaning is actually jumping stone to form soldiers on condition that the person is able to jump over 2 meters high stone will be chosen to be a soldier when the war was to defend their village.

Based on research data that have been obtained, the researcher concluded that the true meaning Hombo Batu is as establishment of warriors to defend their villages is not a requirement to get married. However, because this time the war between villages is no longer there, then Hombo Batu become one of the tourist places can be visited by anyone and from anywhere. Hombo Batu is also one culture that helps people in the economy. Every tourist who ask stone jumper to Hombo Batu attractions, has to pay Rp. 200.000 / jump. Hombo Batu became the one of the culture that is very popular and admired by many people and even the world until now. So these cultures should remain in care, and retained because it has a special attraction and unique.
5.2 Suggestion.

As suitable with the explanation above, the researcher considers that this study is new at Kanjuruhan University of Malang in the language field especially for English Literature. Here, the researcher suggests that this study can give a description as the information to the readers about the real meaning in Hombo Batu culture in Bawomataluo village, Teluk Dalam. There are many kinds of culture in Teluk Dalam district. So, as the researcher, hopefully that others student who want to analyze the meaning in Hombo Batu culture in Bawomataluo village, Teluk Dalam, can use this thesis for guidance to the next analysis but in different aspects. Besides of Hombo Batu culture in Bawomataluo village, Teluk Dalam, the others researcher can learn more about many cultures, perang dance or Fataele, Maena dance, Mogaele Dance, Famadaya Harimao, and so on. Moreover, the researcher suggests that if the readers who wish to analyze Hombo Batu culture perhaps can add the theory taken from other sources which are not included in this thesis. Then, the researcher hopes that all student of Kanjuruhan University of Malang especially the students from Nias Island are interested to study the culture in Hombo Batu 
in Bawomataluo village, specifically for

literary devices that revealed in Nias culture.

Finally, this thesis also motivates all students, especially the students of English Literature, to learn more about cross culture understanding. By learn this analysis hopefully the readers can get more

information and take a good learning on description of Hombo Batu culture.

Specifically, the meaning which is used in Hombo Batu in Bawomataluo village can be applied in communication of society life. 


\section{REFERENCES}

Algeo. (2005). "The origins and development of the English Language". sixth edition. Wadswort. Cengage Learning.

Barbour. (1998). "A process foe developing research in qualitative research". canada.

Brodbeck. (1963). “Explaining and predicting”. Bandung: Remaja Rosadakarya.

Denzin, Norman K., \& Yvonna S. Lincoln (Eds). (2010). "Handbook of Qualitative Research". Sage publication. Pvt. Ltd.

Fernandes, Stephanus Oasias (1990)."Kebijakan manusia nusa tenggara timur dulu dan sekarang". Ledalero: Sekolah tinggi fisafat katolik.

Halliday M.A.K. (1985). “An introduction to fuctional grammari”. London: firsth edition. Edward Arnold Publisher. Ltd.

Halliday M.A.K and Hasan. (1989). "Language, Context, and Tect: Aspect of language in a social - semiotic perspective". Victoria: Deakin University.

Heryanto. (2004). "Sistem plitik suatu pengantar". Yogyakarta. Library.

Koentjaraningrat. (1997). “metode-metode penelitian masyarakat”. Jakarta: Gramedia Pustaka Utama.

John, Locke. (1963). “An essay concerning human understanding”. Penguin classics.

Lofaland. (1971). "Anayzing social setting: A guide to qualitative observation and analysis". Second edition. Wadsworh.

Malinowski, Bronislaw. (1922). "Argonauts of the Western Pacific". London. Routledge and Sons.

Miles and Huberman. (1994). "Qualitative data analysis". Arizona state university.

Ogden and Richards. (1972). "The meaning of meaning". Cambridge: Cambridge university press.

Ogden and Richards. (1946). "Reference Process". Jakarta. Salemba.

Patton. (2001). "Qqualitative research and Evaluation methods". Sage publication. Inc.

Plato. (1963). "The republic". Cambridge: Cambridge university press.

Rohendi. (2000). “Kesenian dalam pendekatan kebudayaan”. Cipta prima nusantara, Semarang. 
Stewart L. Tubbs and Sylvia Moss. (1994). "Human Communication". Remaja rosda karya.

Sobur, A. (2001). “Analysis teks media”. Bandung: Remaja Rosdakarya.

Sobur, A. (2004). “Semiotika komunikasi”. Bandung: Remaja Rosadakarya.

Wittgenstein.(1963). “Tractatus Logico Philosophicus". Routledge and kegan paul. Ltd.

\section{The other sources:}

Interview Emanuel Fau as the son of the leader of Hiliametaniha

Interview with Hikayat Manao as a stone jumper in 1980

Interview with Hadirat Manao as a stone jumper in 1970

Interview with Polius Laia as citizen of Teluk Dalam

Interview the headman of Bawomataluo village 